\title{
Mechanical circulatory support after surgical repair of Bland-White-Garland syndrome. A study of three cases
}

\author{
Girish Sharma ${ }^{1}$, Cyprian Augustyn ${ }^{1}$, Paweł Nawrocki ${ }^{2}$, Romuald Cichoń ${ }^{3}$ \\ ${ }^{1}$ Lower Silesian Center for Heart Diseases, Wroclaw, Poland \\ ${ }^{2}$ Student Research Association operating at the Lower Silesian Center for Heart Diseases, Wroclaw, Poland \\ ${ }^{3}$ Clinic of Cardiac Surgery, $1^{\text {st }}$ Chair and Clinic of Cardiology, $1^{\text {st }}$ Faculty of Medicine, Medical University \\ of Warsaw, Poland
}

Kardiochirurgia i Torakochirurgia Polska 2015; 12 (1): 77-79

\begin{abstract}
The anomalous origin of the left coronary artery arising from the pulmonary artery (ALCAPA), also known as Bland-WhiteGarland (BWG) syndrome, is a rare congenital heart disease. We present cases of three children in whom BWG syndrome was repaired surgically. In two of them, the left coronary artery was transplanted from the pulmonary trunk to the aorta, and in one, the Takeuchi procedure was performed. In both cases in which the left coronary artery was transplanted to the aorta, mechanical circulatory support was used after the surgery. This was due to a low ejection fraction (10\%) while weaning from cardiopulmonary bypass. Although associated with numerous complications, mechanical circulatory support can be a lifesaving therapy in patients with a poor left ventricular function after the correction of BWG syndrome.

Key words: Bland-White-Garland syndrome, mechanical circulatory support.
\end{abstract}

\section{Introduction}

Bland-White-Garland (BWG) syndrome is a congenital heart defect in which the left coronary artery abnormally branches off the pulmonary trunk. Its prevalence is approximately $1: 300,000$ births, which corresponds to approximately $0.4 \%$ of all congenital heart defects $[1,2]$. It is the most frequent cause of myocardial infarction in children; mortality among untreated individuals reaches $90 \%$, while the remaining $10 \%$ survive due to the existence of collateral circulation from the right coronary artery [2]. Depending on the extent of the connections between the coronary arteries, BWG syndrome may present itself at elderly age or remain asymptomatic throughout the patient's life [2, 3]. Symptoms of congestive heart failure, myocardial ischemia, left ventricular contractility impairments, or impairments

\section{Streszczenie}

Zespół Blanda-White'a-Garlanda (BWG) jest wrodzoną wadą serca polegającą na nieprawidłowym odejściu lewej tętnicy wieńcowej od pnia płucnego. W pracy opisano trzy przypadki dzieci, u których wykonano chirurgiczną korekcję opisywanej wady. U dwóch z nich operację wykonano metodą przeszczepienia lewej tętnicy wieńcowej z pnia płucnego do aorty, u jednego zabieg wykonano metodą Takeuchi. W obu przypadkach po operacji metodą przeszczepienia tętnicy do aorty zastosowano mechaniczne wspomaganie krążenia z powodu niskiej frakcji wyrzutowej lewej komory (10\%) przy próbie odłączenia krążenia pozaustrojowego. W przypadku niskiej frakcji wyrzutowej lewej komory terapią dającą szansę na przeżycie jest zastosowanie mechanicznego wspomagania krążenia mimo ryzyka licznych powikłan.

Słowa kluczowe: zespół Blanda-White’a-Garlanda, mechaniczne wspomaganie krążenia.

in the functioning of the mitral valve typically appear at approximately 8 weeks of life [1-3]. The syndrome's subjective manifestations may include dyspnea, fatigability, tearfulness, or paleness [2, 4].

The present study presents cases of two children in whom extracorporeal membrane oxygenation (ECMO) was employed after the surgical repair of BWG syndrome and one child in whom ECMO was not required after this procedure.

\section{Case 1}

A 12-year-old boy diagnosed with BWG syndrome and secondary dilated cardiomyopathy was admitted in order to undergo surgical treatment. Physical examination revealed a systolic murmur above the apex of the heart; no other abnormalities were found. Left ventricular contractil-

Address for correspondence: Paweł Nawrocki, Student Research Association at the Lower Silesian Center for Heart Diseases, 73a Kamieńskiego St., 51-124 Wroclaw, Poland, phone: +48 695460 544, e-mail: pawel.nawrocki.md@gmail.com 
ity was in the lower range of normal levels. The functioning of the mitral valve was normal. During cardiac catheterization, retrograde coronary blood flow was observed from the opening of the left coronary artery in the pulmonary trunk. The location of the coronary opening on the posterolateral wall of the pulmonary trunk precluded coronary artery transplantation. Therefore, using extracorporeal circulation and Takeuchi's procedure, a tunnel was formed inside the pulmonary artery from the outlet of the left coronary artery to the created aortopulmonary window. The procedure and the postoperative course were uneventful. A control ultrasound examination of the heart was performed, yielding normal results. The patient was discharged on the $9^{\text {th }}$ postoperative day in good general condition.

\section{Case 2}

A 4-month-old girl diagnosed with a hemodynamically significant defect - BWG syndrome, third-degree mitral valve insufficiency, and left ventricular heart failure was admitted in order to undergo a repair procedure. Preoperative electrocardiography (ECG) revealed ST-segment elevation in precordial leads V5 and V6 as well as elevation of cardiac markers. The cardiac ejection fraction (EF) was estimated at approx. 38\%, and left ventricular end-diastolic (LVED) diameter - at approx. $39 \mathrm{~mm}$. Cardiac catheterization demonstrated that the trunk of the left coronary artery branched off the posterolateral wall of the pulmonary trunk, which, considering the distance, precluded the implantation of a vascular graft into the aorta. The procedure was performed under extracorporeal circulation; the pulmonary artery was incised transversely above the origin of the left coronary artery; subsequently, a strip of the pulmonary trunk was excised together with the outlet of the left coronary artery. A strip of the aorta, pedicled on the posterior wall, was incised and sutured to the pulmonary trunk strip, creating a tunnel from the outlet of the left coronary artery to the ascending aorta, running outside the pulmonary trunk. The defect in the wall of the pulmonary trunk was repaired with preserved bovine pericardium. The procedure also included atrial septal defect (ASD) closure. After clamp removal, the heart resumed sinus rhythm. Postoperatively, on the day of the procedure, significant left ventricular failure was observed along with impairment of contractility - EF $10 \%$. A decision was made to introduce mechanical left ventricular support using venous-arterial extracorporeal circulation. On the $4^{\text {th }}$ postoperative day, circulatory support was disconnected. Due to pneumonitis, the patient remained in the intensive care unit until the $24^{\text {th }}$ postoperative day. A control cardiac echo performed at discharge from the ICU demonstrated EF of 32\%, LVED diameter of $36 \mathrm{~mm}$, and mitral insufficiency reduced to the second degree. During the following days, the clinical condition of the child improved as the indices of inflammation subsided systematically. The patient was extubated on the $22^{\text {nd }}$ postoperative day. On the $24^{\text {th }}$ postoperative day, the patient was transferred to the pediatric cardiology ward, where she remained for the next four weeks. She was dis- charged home on the $51^{\text {st }}$ postoperative day in good general condition and stable circulatory and respiratory status. Although cardiac ultrasonography revealed generalized left ventricular hypokinesia, it also demonstrated a significant improvement of the ejection fraction ( $E F=48 \%$ ) in comparison to previous examinations; the mitral insufficiency was still present, but its gradual regression was observed.

\section{Case 3}

A 6-month-old girl with body mass of $4.6 \mathrm{~kg}$ was referred to our center in order to undergo surgical repair of BWG syndrome. Her records from the previous hospital included the diagnosis of third-degree mitral insufficiency and left ventricular heart failure. The ejection fraction was $18 \%$; left ventricular dilatation with an akinetic apical aneurysm was observed. Physical examination revealed a quiet systolic murmur audible above the cardiac apex. As in the case of the previous patient, cardiac catheterization demonstrated that the whole left coronary artery branched off the posterolateral wall of the pulmonary trunk. The performed procedure employed the same technique that was used in the case of the previous patient and also involved the closure of ASD. Intraoperative transesophageal cardiac echo demonstrated EF of only $10 \%$. Therefore, a decision was made to introduce mechanical circulatory support instead of extracorporeal circulation and to maintain it during the postoperative period. On the $2^{\text {nd }}$ postoperative day, cardiac echo demonstrated EF of 19\%, LVED diameter of $36 \mathrm{~mm}$, and a reduction of mitral insufficiency from the third to second degree. On the $3^{\text {rd }}$ postoperative day, the vent cannula was removed from the left atrium. On the $5^{\text {th }}$ postoperative day, circulatory support was disconnected. On the $6^{\text {th }}$ day, neurological symptoms appeared in the form of pathological muscle tension and eye movements to the right side. At this point, the patient underwent computed tomography of the head. The examination revealed the presence of fresh diffuse ischemic lesions in both temporal, frontal, and occipital lobes (caused by numerous embolisms originating from the akinetic left ventricular apex). The patient was extubated on the $23^{\text {rd }}$ postoperative day. On the $30^{\text {th }}$ day, the patient was transferred to the pediatric cardiology ward, where she continued to undergo catecholamine therapy. A systematic regression of neurological symptoms was noted, but left-sided hemiparesis persisted. After further seven weeks of treatment, the patient was discharged home in good general condition and stable circulatory and respiratory status. The ejection fraction at discharge was $33 \%$. Mitral insufficiency persisted at the second degree according to Simpson. Regular follow-up visits to cardiology and neurology clinics were recommended to the patient.

\section{Discussion}

The treatment for BWG syndrome is surgical repair [4]. The following techniques are reported to be feasible in this context: creating a bypass from the aorta to the left coronary artery or the descending branch of the left coronary artery (LAD), transplanting the left coronary artery along 
with its outlet from the pulmonary trunk to the aorta, or forming a tunnel from the wall of the pulmonary trunk, connecting the left coronary artery with the aorta and running inside the pulmonary trunk - using Takeuchi's method [5] - or outside the pulmonary trunk [6]. The method which appears to offer best results consists in transplanting the left coronary artery to the aorta. Its use is limited by anatomic variants which preclude repairing the defect in this manner $[5,6]$. In this situation, Takeuchi's technique may be used, or a connecting tunnel may be created outside the pulmonary trunk $[5,6]$. This method of repair was used in patients 2 and 3, while Takeuchi's procedure was employed in patient 1 . This technique offers very good early results, but is sometimes followed by long-term complications such as pulmonary artery stenosis or shunt from the tunnel to the lumen of the pulmonary trunk [6].

Although patients 2 and 3 exhibited third-degree mitral insufficiency, no repair procedure was attempted, as the insufficiency was caused by generalized hypokinesia and left ventricular dilatation. In such cases, it is difficult to assess the actual degree of insufficiency.

Although mechanical circulatory support employing extracorporeal circulation has been used for many years in the treatment of heart and lung diseases, clear qualifying criteria for its use are still lacking [7]. The primary reasons for its use in children include a low ejection fraction after cardiac surgery procedures $[7,8]$. The most significant complications resulting from using this method include bleeding, sepsis, and ischemic or hemorrhagic changes within the central nervous system [7]. Longer duration of therapy entails a lower chance of recovery and a higher risk of complications [7]. The subject literature features reports of cases similar to ours in that they required the use of mechanical circulatory support after the surgical repair of BWG syndrome $[1,6]$.

\section{Conclusions}

Despite the risk of numerous complications, mechanical circulatory support offers a chance of survival to patients with a low left ventricular ejection fraction. As this is a frequent problem after the surgical repair of BWG syndrome, the authors suggest that such repair should only be performed in centers that are able to provide mechanical circulatory support.

\section{Disclosure}

Authors report no conflict of interest.

\section{References}

1. Barbetakis N, Efstathiou A, Efstathiou N, Papagiannopoulou P, Soulountsi V, Fessatidis I. A long-term survivor of Bland-White-Garland syndrome with systemic collateral supply: A case report and review of the literature. BMC Surg 2005; 5: 23.

2. Callaghan MA, O'Hare B, Casey W. What other anomalies? Failure to wean post ventricular septal defect repair secondary to anomalous origin of the left coronary artery from the pulmonary artery. Paediatr Anaesth 2012; 22: 487-489.

3. Kazmierczak P, Ostrowska K, Dryzek P, Moll JA, Moll JJ. Repair of anomalous origin of the left coronary artery from the pulmonary artery in infants. Interact Cardiovasc Thorac Surg 2013; 16: 797-801.

4. Karolczak MA, Wieteska J, Bęc L, Mądry W. Anomalous origin of the left coronary artery (LCA) from pulmonary trunk (Bland-White-Garland syndrome) with systemic collateral supply. Med Sci Monit 2001; 7: 755-758.

5. Takeuchi S, Imamura H, Katsumoto K, Hayashi I, Katohgi T, Yozu R, Ohkura $M$, Inoue T. New surgical method for repair of anomalous left coronary artery from pulmonary artery. J Thorac Cardiovasc Surg 1979; 78: 7-11.

6. Sodian R, Rassoullian D, Beiras-Fernandez A, Loeff M, Schmitz C, Reichart B, Daebritz S. ALCAPA with the Ectopic Orifice at the Non-Facing Sinus Successful Anatomic Repair by Creation of an Autologous Extrapulmonary Tunnel. Tex Heart Inst J 2008; 35: 32-35.

7. Brown KL, Goldman AP. Neonatal extra-corporeal life support: Indications and limitations. Early Hum Dev 2008; 84: 143-148.

8. Morris MC, Ittenbach RF, Godinez RI, Portnoy JD, Tabbutt S, Hanna BD, Hoffman TM, Gaynor JW, Connelly JT, Helfaer MA, Spray TL, Wernovsky G. Risk factors for mortality in 137 pediatric cardiac intensive care unit patients managed with extracorporeal membrane oxygenation. Crit Care Med 2004; 32: 1061-1069. 